\title{
Renal changes and acute kidney injury in covid-19: a systematic review
}

\author{
D Samuel Átila Rodrigues Nogueira ${ }^{1}$ \\ (iD) Samuel Ciríaco Silva de Oliveira ${ }^{1}$ \\ (i) Ana Flávia Moreira de Carvalho ${ }^{1}$ \\ (D) Julia Moreira Cavalcante Neves ${ }^{1}$ \\ (D) Leila Silveira Vieira da Silva ${ }^{1}$ \\ (D) Geraldo Bezerra da Silva Junior ${ }^{2}$ \\ (iD) Maria Elizabeth Pereira Nobre ${ }^{1}$
}

1. Universidade Federal do Cariri, Faculdade de Medicina, Barbalha, CE, Brasil. 2. Universidade de Fortaleza, Curso de Medicina, Programas de Pós-Graduação em Saúde Coletiva e Ciências Médicas, Fortaleza, CE, Brasil.

\section{SUMMARY}

OBJECTIVE: We aimed to present a review of renal changes in patients with COVID-19.

METHODS: We performed a systematic review of the literature to identify original articles regarding clinical, laboratory, and anatomopathological kidney changes in patients infected with SARS-CoV-2 published until May 7,2020. The search was carried out across PubMed, Scopus, and Embase using the keywords "COVID-19", "coronavirus", "SARS-CoV-2", "kidney injury" and "kidney disease". Fifteen studies presented clinical and laboratory renal changes in patients with COVID-19, and three addressed anatomopathological changes. DISCUSSION: Acute kidney injury (AKI) was a relevant finding in patients with COVID-19. There were also significant changes in laboratory tests that indicated kidney injury, such as increased serum creatinine and blood urea nitrogen (BUN), proteinuria, and hematuria. The presence of laboratory abnormalities and AKI were significant in severely ill patients. There was a considerable prevalence of AKI among groups of patients who died of COVID-19. Histopathological analysis of the kidney tissue of patients infected with SARS-CoV-2 suggested that the virus may directly affect the kidneys.

CONCLUSION: Although COVID-19 affects mainly the lungs, it can also impact the kidneys. Increased serum creatinine and BUN, hematuria, proteinuria, and AKI were frequent findings in patients with severe COVID-19 and were related to an increased mortality rate. Further studies focusing on renal changes and their implications for the clinical condition of patients infected with the novel coronavirus are needed.

KEYWORDS: Coronavirus. Coronavirus Infections. Betacoronavirus. Acute Kidney Injury. Renal Insufficiency.

\section{INTRODUCTION}

The coronaviruses are RNA viruses of the Coronaviridae family and the Nidovirales order'. Many of them are zoonotic viruses that can infect humans, causing mild diseases, such as colds, or even serious illnesses, such as the betacoronaviruses, responsible for the epidemics of Severe Acute Respiratory Syndrome (SARS-CoV) and the Middle East Respiratory Syndrome (MERS-CoV) ${ }^{2.3}$. 
A new respiratory syndrome similar to those caused by SARS-CoV and MERS-CoV emerged in Wuhan, China, at the end of $2019^{4.5}$. The etiologic agent was identified as a new coronavirus, which received the name SARS-CoV-2, and the disease it causes was named Coronavirus Disease 2019 (COVID-19) ${ }^{6}$. Until the beginning of May 2020, there were over 4 million confirmed cases and 300,000 deaths due to SARS-CoV-2 throughout the world, a health crisis of proportions never before seen in the contemporary world ${ }^{7}$.

The pathological characteristics of these diseases are similar, with the involvement of several tissues, such as the lungs, liver, intestine, and central nervous system $^{1,8-10}$. There are also reports of compromised kidney function during MERS-CoV and SARS-CoV infections ${ }^{11.12}$.

The main clinical manifestations of COVID-19 include fever, cough, fatigue, and dyspnea ${ }^{13}$. A large proportion of patients presented deregulation of organic functions, usually respiratory and of the heart ${ }^{14}$. However, a significant number of patients presented acute kidney injury (AKI) during the clinical course ${ }^{15-17}$. In the same line, some studies have reported a possible interface between SARS-CoV-2 and the kidney ${ }^{18-20}$.

Given the urgency in getting answers about how the SARS-CoV-2 infection behaves, this work aims to present an update of the literature in order to understand the relationship between COVID-19 and its renal complications, particularly AKI.

\section{METHODS}

A systematic review of the literature was conducted in the PubMed, Scopus, and Embase electronic databases, using the keywords: "COVID-19", "coronavirus", "Sars-CoV-2", "kidney injury" and "kidney disease", according to PRISMA ${ }^{21}$. We selected original articles published up until May 7, 2020 and extracted the data related to clinical manifestations, laboratory findings, and pathological findings associated with kidney involvement in COVID-19. The primary outcome was to analyze the kidney effects and AKI in patients infected by SARS-CoV-2.

In the end, 18 papers were selected as relevant for the qualitative synthesis (Figure 1). Of these, 15 addressed the clinical and laboratory data of COVID-19 patients (Tables 1 and 2). Another 3 papers exposed anatomopathological alterations.

TABLE 2. STUDIES SHOWING PROTEINURIA AND HEMATURIA AMONG PATIENTS WITH COVID-19, DECEMBER 2019 TO MAY 2020*

\begin{tabular}{l|l|l|} 
Authors & $\begin{array}{l}\text { Urinary Protein } \\
\text { On Admission }\end{array}$ & $\begin{array}{l}\text { Urinary Occult } \\
\text { Blood On Admission }\end{array}$ \\
\hline Cheng, et al., (2020)19 & $43.9 \%$ & $26.7 \%$ \\
\hline Chen, et al., (2020) & $60.24 \%$ [a] & $50.6 \%$ [a] \\
\hline Pei, et. al., (2020) ${ }^{\mathbf{2 9}}$ & $65.8 \%$ & $41.7 \%$ \\
\hline "By May 7, 2020; [a] Regarding patients who underwent routine urine testing $(n=166) ;$
\end{tabular}

TABLE 1. STUDIES ON ACUTE KIDNEY INJURY (AKI) IN PATIENTS WITH COVID-19, DECEMBER 2019 TO MAY 2020*

\begin{tabular}{|c|c|c|c|c|}
\hline Authors & $\begin{array}{l}\text { Total Number } \\
\text { of Patients }\end{array}$ & $\begin{array}{l}\text { Incidence of } \\
\mathrm{AKI}(\%)\end{array}$ & $\begin{array}{l}\text { Serum Creatinine }(\mu \mathrm{mol} / \mathrm{L}) \\
\text { On Admission }\end{array}$ & $\begin{array}{l}\text { Blood Urea Nitrogen (mmol/L) On } \\
\text { Admission }\end{array}$ \\
\hline Zhang, et al., (2020) ${ }^{17}$ & 221 & $4.5^{[a]}$ & $69.0(56.0-84.0)^{[b]}$ & $4.3(3.4-5.6)^{[b]}$ \\
\hline Cheng, et al., (2020) ${ }^{19}$ & 701 & $5.1^{[\mathrm{c}]}$ & Elevated in $14.4 \%(77.0 \pm 31.0)^{[\mathbf{d}]}$ & Elevated in $13.1 \%(5.7 \pm 3.9)^{[\mathbf{d}]}$ \\
\hline Shi, et al., $(2020)^{22}$ & 416 & 1.9 & $59.23(48.62-71.60)^{[\mathbf{b}]}$ & - \\
\hline Chen, et al., (2020) ${ }^{14}$ & 274 & 11 & $76.0(58.0-94.0)^{[b]}$ & $4.9(3.5-7.9)^{[\mathbf{b}]}$ \\
\hline Deng, et al., $(2020)^{23}$ & 225 & 8.89 & - & $89.0(72.0,133.5)$ vs. $65.0(54.6,78.75)^{[\mathrm{e}]}$ \\
\hline Yang, et al., (2020) ${ }^{15}$ & 52 & 29 & - & 76.3 (27.4) vs. $80.7(32.3)^{[\mathrm{f}]}$ \\
\hline Richardson, et al., (2020) ${ }^{24}$ & 2.634 & 22.2 & - & - \\
\hline Li, et al., $(2020)^{25}$ & 54 & 70.7 & - & - \\
\hline Wang, et al., (2020) ${ }^{26}$ & 116 & 0.0 & $78.26 \pm 25.14^{[\mathrm{g}]}$ & $5.23 \pm 1.72^{[\mathrm{g}]}$ \\
\hline Li, et. al., $(2020)^{27}$ & 25 & - & $66.0(49.5-161.0)^{[b]} 33.3 \%[\mathrm{~h}]$ & $9.29(6.07-16.4)^{[b]} 43.5 \%{ }^{[h]}$ \\
\hline Wang, et. al., (2020) ${ }^{\mathbf{2 8}}$ & 107 & 13.1 & $71.0(60.0-86.0)^{[b]}$ & $4.2(3.2-5.6)^{[b]}$ \\
\hline Pei, et. al., $(2020)^{29}$ & 333 & 10.5 & $70.0(57.0-84.0)^{[i]}$ & $4.3(3.2-5.7)^{[i]}$ \\
\hline Zhao, et al., (2020) $)^{30}$ & 91 & 5.5 & $\leq 97.0(94.5 \%),>97.0(5.5 \%)^{[j]}$ & $\leq 417.0(94.5 \%),>417.0(5.5 \%)^{[j]}$ \\
\hline Yang, et al., (2020) & 92 & 15.4 & $86.0(34.0-428.0)^{[\mathbf{b}]}$ & $8.9(3.4-48.0)^{[\mathbf{b}]}$ \\
\hline
\end{tabular}

*By May 7, 2020; [a] Of the 221 patients, the majority were still hospitalized at the time of data collection; [b] Median (IQR); [c] Stage 1: 1.9\%, Stage 2: 1.3\%, Stage 3: 2\%; [d] Mean \pm SD; [e] Dead $(n=109)$ vs. Recovered $(n=116)$, Median (Q1, Q3); [f] Survivors $(n=20)$ vs. Non-survivors $(n=32)$, Mean (SD); [g] Number of patients without CKD ( $n=111) ;[h]$ Above the upper limit of normality; [i] Median (25th-75th percentil); [j] Uric acid $(\mu \mathrm{mol} / \mathrm{L})$ instead of blood urea nitrogen ( $\mathrm{mmol} / \mathrm{L})$; 
FIGURE 1. FLOWCHART SUMMARIZING THE SEARCH STRATEGY FOR STUDIES (KIDNEY INJURY AND COVID-19). ADAPTED FROM MOHER ET AL. (DOI.ORG/10.1371/JOURNAL.PMED.1000097)@2009, UNDER TERMS OF CREATIV COMMONS ATTRIBUTION 4.O INTERNATIONAL LICENCE (CREATIVECOMMONS.ORG/LICENSES/BY/4.O/ LEGALCODE).

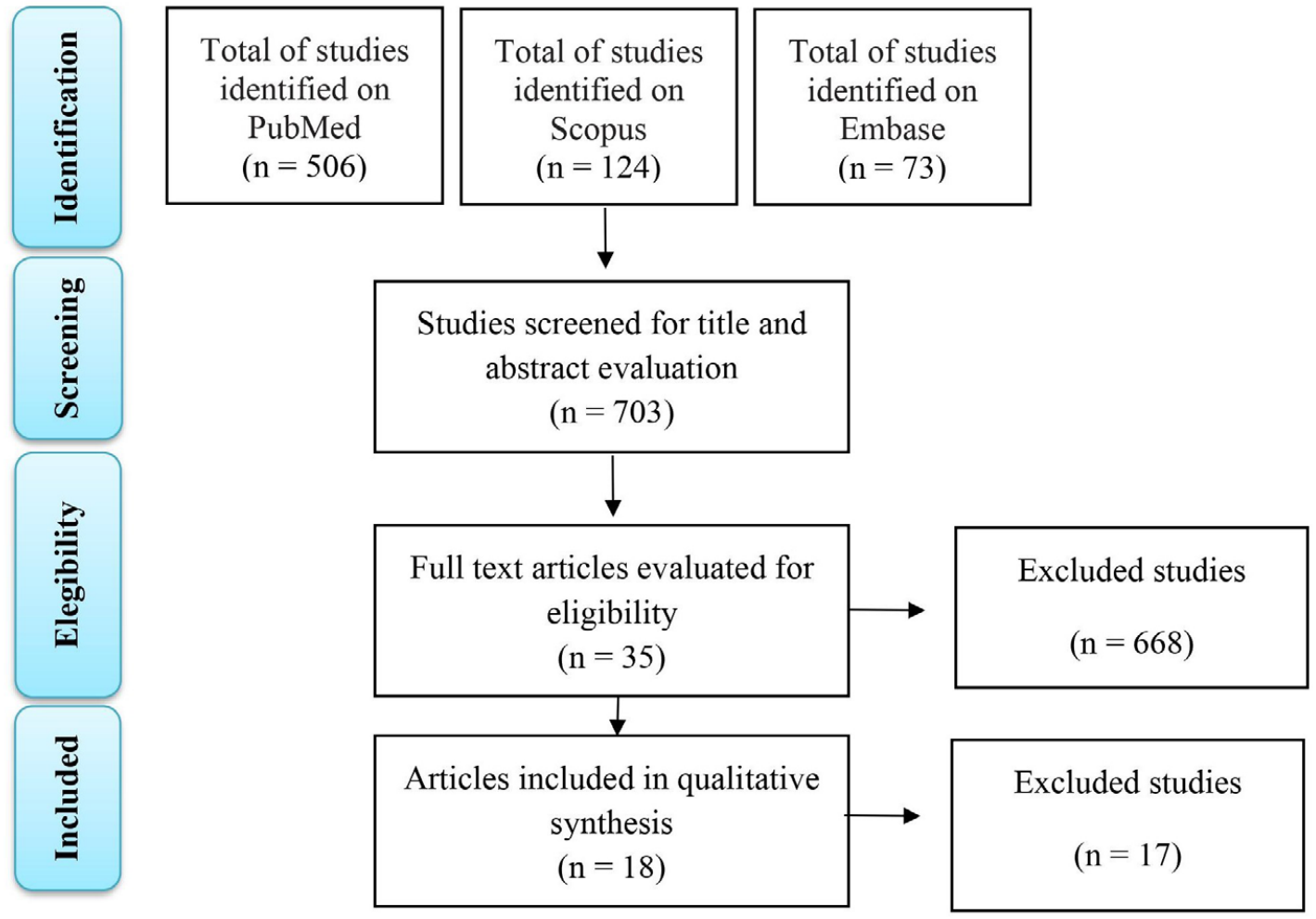

\section{DISCUSSION}

Studies show that SARS-CoV-2 can infect the alveolar epithelial cells of the lungs through the angiotensin-converting enzyme-II (ACEII) receptor, which is also expressed in other tissues, such as the kidneys ${ }^{17}$. After pulmonary infection, the virus would enter the bloodstream and accumulate in the kidneys, causing damage to the kidney tubular epithelial cells through an ACEII-dependent pathway ${ }^{19}$. Pei et al. ${ }^{29}$ suggested that acute tubular necrosis (ATN) is the main cause of AKI in COVID-19. In their study, a patient with AKI had, in their urine protein electrophoresis, a high proportion of tubular renal protein.

Several studies have described renal involvement mainly due to AKI, which can affect up to 70\% of COVID19 patients (Table 1); the kidney is the second most affected organ in the disease, behind the lung and followed by the heart and the liver ${ }^{25}$. Li et al. ${ }^{27}$ also found the kidney was the most affected organ, except for the lung and heart. In contrast, a study conducted by the University of Wuhan, China, showed that of the 116 hospitalized patients due to COVID-19, only $10.35 \%$ had a slight increase in the level of serum urea or creatinine, without meeting the criteria for $\mathrm{AKI}^{26}$. This study was an exception among those selected in our work.

In general, serum creatinine values were the main parameter for the diagnosis of AKI, following the criteria of the Kidney Disease: Improving Global Outcomes (KDIGO). In most studies, their values were measured at the time of patient admission (Table 1) and varied based on the severity of the condition. Yang et al. ${ }^{32}$ found that $50 \%$ of the patients with AKI already had a high rate of serum creatinine at the time of admission. Patients with a normal rate of serum creatinine on admission had an increase in the second test, followed by a decrease in the glomerular filtration rate $^{32}$. Among the values found for serum creatinine, the biggest alterations were in patients who needed intensive care and/or died due to the new coronavirus disease. According to Cheng et al. ${ }^{19}$, patients with high basal serum creatinine had a higher leukocyte count and a lower count of lymphocytes and platelets. Abnormalities in the coagulation cascade, including extended activated partial thromboplastin time (aPTT) and higher D-dimer value, were common ${ }^{19}$. 
Cheng et al. ${ }^{19}$ demonstrated an average of serum urea of $5.7 \mathrm{mmol} / \mathrm{L}$ in the patients of the study, reaching an average of $11 \mathrm{mmol} / \mathrm{L}$ in patients with increased serum creatinine. As to the rate of glomerular filtration, we observed an average of $87 \mathrm{~mL} /$ $\mathrm{min} / 1.73 \mathrm{~m}^{2}$ when considering all the patients, and $48 \mathrm{~mL} / \mathrm{min} / 1.73 \mathrm{~m} 2$ in patients with increased serum creatinine, which corroborates the development of kidney failure in the latter. Approximately $13.1 \%$ of the infected patients presented a glomerular filtration rate $<60 \mathrm{~mL} / \mathrm{min} / 1.73 \mathrm{~m} 2$ at the time of hospital admission ${ }^{19}$. In the same sense, Yang et al..$^{31}$ found that, on admission, the median (IQR) of the glomerular filtration rate of the 92 patients included in the study was $89.6 \mathrm{~mL} / \mathrm{min} / .73 \mathrm{~m}^{2}$ (9-135). Another study in China found proteinuria and microscopic hematuria in, respectively, $60.24 \%$ and $50.6 \%$ of the patients who underwent routine urine examination (Table 2$)^{14}$.

Kidney complications can occur at any time during the course of the disease and are increasingly being described as late ${ }^{32}$. The pathogenesis of kidney injury in COVID-19 has not yet been defined, but it has been observed that the presence of comorbidities can influence its development ${ }^{32}$. In this sense, Yang et al. ${ }^{32}$ have shown an incidence of kidney injury in patients with renal comorbidities significantly higher than in those without comorbidities ( $54.5 \%$ vs $2.0 \%$, $\mathrm{p}<0.001)$. Cheng et al. ${ }^{19}$ found that out of all the patients with abnormalities in kidney function, $13 \%$ had an underlying kidney disease and $2 \%$ a history of chronic kidney disease (CKD). In addition, the percentage of patients who developed AKI was higher in the diabetic subgroup, compared to non-diabetic patients ${ }^{15}$.

Cheng et al. ${ }^{19}$ emphasize that patients with a history of CKD exhibit a pro-inflammatory state with functional defects in innate and acquired immunity and are recognized as a population at greater risk for infections. However, this alone is not enough to explain the frequent occurrence of AKI in COVID-19 patients, and perhaps it only corroborates what was demonstrated by Yang et al. ${ }^{32}$, who demonstrated that patients with kidney comorbidities are more susceptible to the development of AKI, although this does not apply exclusively to them. Pei et al. ${ }^{29}$ suggested that the severity of pneumonia was the main risk factor for the development of AKI in COVID-19 patients.

The risk factors and causes of AKI in COVID-19 are diverse. Serum creatinine was a widely used marker to detect kidney involvement. However, new biomarkers of kidney injury, such as neutrophil gelatinase-associated lipocalin (NGAL), monocyte chemotactic protein-1 (MCP-1), and interleukins, have been applied to infectious diseases and could be valuable for detecting early kidney involvement in COVID-1933.

\section{SEVERITY AND MORTALITY}

There is a link between the severity of COVID-19 patients and kidney status. AKI was a frequent finding in severe patients, found in $29 \%$ of them, while only $1.2 \%$ of non-severe cases developed this complication ${ }^{17}$. In the same way, the increase in basal serum creatinine was correlated with a worsening of clinical condition ${ }^{17.19}$. Cheng et al. ${ }^{19}$ found a significant difference regarding the number of severe patients between the groups of patients with high and normal basal serum creatinine (52.5\% vs. $40.7 \%$, $p=0.026)$.

Many studies found higher mortality in COVID-19 patients who had kidney complications. Chen et al. ${ }^{14}$ found that $25 \%$ of the patients who died presented AKI, while only $1 \%$ of the patients recovered presented this complication. Another important finding of this study was that, of the 29 patients who had AKI, 96.55\% $\operatorname{died}^{14}$. Several studies presented similar data, with the presence of AKI in a considerable portion of dead patients: $62 \%$ in the study by Richardson et al. ${ }^{24}$ and $32 \%$ in Yang et al. ${ }^{15}$. Wang et al..$^{28}$ highlighted a significant prevalence of AKI (73.7\%) in dead patients and none in recovered ones.

In this sense, Cheng et al. ${ }^{19}$ analyzed data from 701 patients in China. Part of the patients already presented renal alterations in hospital admission, such as increased serum creatinine (14.4\%), high serum urea (13.1\%), proteinuria (43.9\%), and hematuria (26.7\%). During the hospital stay, 5.1\% of the studied group developed AKI. The authors concluded that the rate of in-hospital mortality was significantly higher in patients who presented these kidney alterations and that any degree of proteinuria, hematuria, elevated basal serum urea, peak serum creatinine $>133 \mu \mathrm{mol} / \mathrm{L}$, and AKI above stage 2 are associated with in-hospital death of COVID-19 patients ${ }^{19}$.

The mean serum urea of dead patients compared to the mean of recovered patients was $8.4 \mathrm{mmol} / \mathrm{L}$ and $4.0 \mathrm{mmol} / \mathrm{L}$, respectively ${ }^{14}$. The same was observed in the comparison of serum creatinine means: $88 \mu \mathrm{mol} / \mathrm{L}$ in dead patients and $66 \mu \mathrm{mol} / \mathrm{L}$ in recovered patients ${ }^{14}$. The incidence of in-hospital death in patients with high basal serum creatinine was $33.7 \%$, which was 
considerably higher than in those with normal basal serum creatinine $(13.2 \%)^{19}$. Upon analyzing the urine from COVID-19 patients, hematuria and proteinuria were frequent findings during the hospital stay, present in $82 \%$ and $86 \%$ of dead patients, respectively ${ }^{14}$.

Pei et al. ${ }^{29}$ found similar results, with a higher mortality rate in patients who had kidney involvement (11.2\%), compared to those who had no kidney involvement (1.2\%). In this study, $4.7 \%$ of the group presented AKI. Of these, $86.4 \%$ died, which was the outcome of $75 \%$ of the patients with stage $1 \mathrm{AKI}, 85.7 \%$ of patients with stage $2 \mathrm{AKI}$, and $90.9 \%$ of the patients with stage 3 AKI.

As seen, a large proportion of patients with severe COVID-19 developed some type of kidney involvement. AKI seems to have affected particularly patients who died from COVID-19. There is a considerable prevalence of this alteration in patients who died, which could indicate a correlation with higher mortality in patients infected by SARS-CoV-2.

\section{COVID-19 AND RENAL PATHOLOGY}

SARS-CoV-2 is $79 \%$ homologous with SARS-CoV, and both belong to the betacoronavirus genera, which uses the same ACEII receptor as a means of entry into the target cells ${ }^{20}$. Therefore, it is likely that the new coronavirus uses a similar mechanism ${ }^{20}$. The high expression of the angiotensin-converting enzyme type II (ACEII) in the kidneys could explain why these organs are possible targets ${ }^{34}$. Su et al..$^{20}$, in a study with patients who died from COVID-19, found that the ACEII protein was abnormal in $60 \%$ of them.

In a renal histopathological analysis of COVID-19 patients, changes were found in the epithelial and endothelial cells ${ }^{20.35}$. There was a variety of cellular abnormalities, with acute injury of the proximal tubule present in all patients analyzed ${ }^{20}$.

There is evidence suggesting that the SARSCoV-2 virus can directly infect renal tissues ${ }^{20.35}$. In an ultrastructural and immunostaining analysis, it was observed that diffuse acute tubular injury with loss of brush border and non-isometric vacuolization could be partially caused by direct infection ${ }^{20}$. Wichmann et al. ${ }^{34}$ detected viral RNA in $41.66 \%$ of the renal tissues. Similarly, Su et al. ${ }^{20}$ assessed that AKI and proteinuria in these patients may be associated with the kidney tubule epithelial and podocyte infection by SARS-CoV-2.

\section{CONCLUSION}

COVID-19 is a disease that, despite affecting primarily the lungs, can also affect other organs such as the kidneys. The increase in nitrogenous waste, hematuria, proteinuria, and AKI were frequent findings in patients with severe COVID-19. These findings were correlated with a higher mortality rate. We emphasize the need for more studies focused on kidney alterations and biomarkers ${ }^{34}$ since detection and early treatment can contribute to decreasing the severity and mortality in COVID-19.

\section{Acknowledgments}

We thank the Federal University of Cariri and all the scientists and health professionals who work hard in the fight against the SARS-CoV-2 pandemic.

The authors declare there are no conflicts of interest in professional or financial nature, and no direct or indirect benefits were obtained from this work.

\section{Author's Contribution}

Samuel Átila Rodrigues Nogueira, Samuel Ciríaco Silva de Oliveira, Ana Flávia Moreira de Carvalho, Julia Moreira Cavalcante Neves, Leila Silveira Vieira da Silva, Geraldo Bezerra da Silva Junior and Maria Elizabeth Pereira Nobre: made substantial contributions to the concept and design of the work, the collection, analysis, and interpretation of data, the drafting of the paper and its critical review, and the final approval of the version to be published.

\section{RESUMO}

OBJETIVO: Apresentar uma revisão sobre as alterações renais nos pacientes com COVID-19.

MÉTODOS: Foi realizada uma revisão sistemática de literatura para buscar estudos referentes a pacientes com alterações renais clínicas, laboratoriais e anatomopatológicas durante a infecção por SARS-CoV-2. A busca foi realizada nas bases de dados eletrônicos PubMed, Scopus e Embase, com as palauras-chaves: "COVID-19", "coronavirus", "Sars-CoV-2", "kidney injury" e "kidney disease", para identificar artigos originais publicados na literatura até 07 de maio de 2020. Quinze estudos trouxeram alterações renais clínicas e laboratoriais dos pacientes com COVID-19, e três abordaram análises anatomopatológicas. 
DISCUSSÃO: A Lesão renal aguda (LRA) foi um achado relevante nos pacientes com COVID-19. Houve também alterações significativas nos exames laboratoriais que indicam lesão renal, como o nível de creatinina e ureia séricas, proteinúria e hematúria. As alterações laboratoriais e a LRA foram importantes nos pacientes que desenvolveram o quadro grave da doença. Há considerável prevalência de LRA nos grupos de pacientes que vieram a óbito. Na análise histopatológica de pacientes com SARS-CoV-2 foram encontrados achados renais sugestivos que o vírus poderia ter efeitos diretos sobre o rim.

CONCLUSÃO: A COVID-19 é uma doença que, apesar de acometer principalmente os pulmões, também acomete os rins. Aumento das escórias nitrogenadas, hematúria, proteinúria e LRA foram achados frequentes em pacientes com quadros graves da COVID-19. Esses achados foram relacionados a maior mortalidade. É necessária a realização de mais estudos com enfoque nas alterações renais e suas implicações no quadro clínico causadas pelo novo coronavírus.

PALAVRAS-CHAVE: Coronavirus. Infecções por Coronavirus. Betacoronavirus. Lesão Renal Aguda. Insuficiência Renal.

\section{REFERENCES}

1. Yin C. Genotyping coronavirus SARS-CoV-2: methods and implications. Genomics. 2020;S0888-7543(20)30318-9.

2. Ksiazek TG, Erdman D, Goldsmith CS, Zaki SR, Peret T, Emery S, et al; SARS Working Group. A novel coronavirus associated with severe acute respiratory syndrome. N Engl | Med. 2003;348(20):1953-66.

3. Zaki AM, van Boheemen S, Bestebroer TM, Osterhaus AD, Fouchier RA solation of a novel coronavirus from a man with pneumonia in Saudi Arabia. New Engl | Med. 2012;367(19):1814-20.

4. Hui DS, Azhar El, Madani TA, Ntoumi F, Kock R, Dar O, et al. The continuing 2019-nCoV epidemic threat of novel coronaviruses to global health the latest 2019 novel coronavirus outbreak in Wuhan, China. Int | Infect Dis. 2020;91:264-6.

5. Lu H, Stratton CW, Tang YW. Outbreak of pneumonia of unknown etiology in Wuhan, China: the mystery and the miracle. J Med Virol. 2020;92(4):401-2.

6. Zhu N, Zhang D, Wang W, Li X, Yang B, Song J, et al; China Novel Coronavirus Investigating and Research Team. A novel coronavirus from patients with pneumonia in China, 2019. New Engl | Med. 2020;382(8):727-33.

7. Johns Hopkins University \& Medicine. COVID-19 map [Internet]. Baltimore: Johns Hopkins Coronavirus Resource Center; 2020. [cited 2020 May 18]. Available from: https://coronavirus.jhu.edu/map.htm

8. Xu Z, Shi L, Wang Y, Zhang J, Huang L, Zhang C, et al. Pathological findings of COVID-19 associated with acute respiratory distress syndrome. Lancet Resp Med. 2020;8(4):420-2.

9. Ding Y, Wang H, Shen H, Li Z, Geng J, Han H, et al. The clinical pathology of severe acute respiratory syndrome (SARS): a report from China. J Pathol. 2003;200(3):282-9.

10. Ng DL, Al Hosani F, Keating MK, Gerber SI, Jones TL, Metcalfe MG, et al. Clinicopathologic, immunohistochemical, and ultrastructural findings of a fatal case of Middle East respiratory syndrome coronavirus infection in the United Arab Emirates, April 2014. Am J Pathol. 2016;186(3):652-8.

11. Cha RH, Joh JS, Jeong I, Lee JY, Shin HS, Kim G, et al; Critical Care Team of National Medical Center. Renal complications and their prognosis in Korean patients with Middle East respiratory syndrome-coronavirus from the central MERS-CoV designated hospital. J Korean Med Sci. 2015;30(12):1807-14.

12. Chu KH, Tsang WK, Tang CS, Lam MF, Lai FM, To KF, et al. Acute renal impairment in coronavirus-associated severe acute respiratory syndrome. Kidney Int. 2005;67(2):698-705.

13. Wang D, Hu B, Hu C, Zhu F, Liu X, Zhang J, et al. Clinical characteristics of 138 hospitalized patients with 2019 novel coronavirus-infected pneumonia in Wuhan, China. JAMA. 2020;323(11):1061-9.

14. Chen T, Wu D, Chen H, Yan W, Yang D, Chen G, et al. Clinical characteristics of 113 deceased patients with coronavirus disease 2019: retrospective study. BMJ. 2020;368:m1091.

15. Yang $X, Y u Y, X u$ J, Shu $H$, Xia J, Liu H, et al. Clinical course and outcomes of critically ill patients with SARS-CoV-2 pneumonia in Wuhan, China: a single-centered, retrospective, observational study. Lancet Respir Med. 2020;8(5):475-81.

16. Huang C, Wang Y, Li X, Ren L, Zhao J, Hu Y, et al. Clinical features of patients infected with 2019 novel coronavirus in Wuhan, China. Lancet. 2020;395(10223):497-506.

17. Zhang G, Hu C, Luo L, Fang F, Chen Y, Li J, et al. Clinical features and short-term outcomes of 221 patients with COVID-19 in Wuhan, China. I Clin Virol. 2020;127:104364

18. Pan XW, Xu D, Zhang H, Zhou W, Wang LH, Cui XG. Identification of a potential mechanism of acute kidney injury during the COVID-19 outbreak: a study based on single-cell transcriptome analysis. Intensive Care Med. 2020;46(6):114-6.

19. Cheng Y, Luo R, Wang K, Zhang M, Wang Z, Dong L, et al. Kidney disease is associated with in-hospital death of patients with COVID-19. Kidney Int. 2020;97(5):829-38

20. Su H, Yang M, Wan C, Yi LX, Tang F, Zhu HY, et al. Renal histopathological analysis of 26 postmortem findings of patients with COVID-19 in China. Kidney Int. 2020;S0085-2538(20)30369-0.

21. Moher D, Liberati A, Tetzlaff J, Altman DG; PRISMA Group. Preferred reporting items for systematic reviews and meta-analyses: the PRISMA statement. PLoS Med. 2009;6(7):e1000097.

22. Shi S, Qin M, Shen B, Cai Y, Liu T, Yang F, et al. Association of cardiac injury with mortality in hospitalized patients with COVID-19 in Wuhan, China. JAMA Cardiol. 2020;e200950.

23. Deng Y, Liu W, Liu K, Fang YY, Shang J, Zhou L, et al. Clinical characteristics of fatal and recovered cases of coronavirus disease 2019 in Wuhan, China: a retrospective study. Chin Med J (Engl). 2020;133(11):1261-7.

24. Richardson S, Hirsch JS, Narasimhan M, Crawford JM, McGinn T, Davidson $\mathrm{KW}$, et al. Presenting characteristics, comorbidities, and outcomes among 5700 patients hospitalized with COVID-19 in the New York City area. JAMA. 2020;323(20):2052-9

25. Li Y, Hu Y, Yu J, Ma T. Retrospective analysis of laboratory testing in 54 patients with severe- or critical-type 2019 novel coronavirus pneumonia. Lab Invest. 2020;100(6):794-800.

26. Wang L, Li X, Chen H, Yan S, Li D, Li Y, et al. Coronavirus disease 19 infection does not result in acute kidney injury: an analysis of 116 hospitalized patients from Wuhan, China. Am J Nephrol. 2020;51(5):343-8.

27. Li X, Wang L, Yan S, Yang F, Xiang L, Zhu J, et al. Clinical characteristics of 25 death cases with COVID-19: a retrospective review of medical records in a single medical center, Wuhan, China. Int | Infect Dis. 2020;94:128-32.

28. Wang D, Yin Y, Hu C, Liu X, Zhang X, Zhou S, et al. Clinical course and outcome of 107 patients infected with the novel coronavirus, SARS-CoV-2, discharged from two hospitals in Wuhan, China. Crit Care. 2020;24(1):188.

29. Pei G, Zhang Z, Peng J, Liu L, Zhang C, Yu C, et al. Renal involvement and early prognosis in patients with COVID-19 pneumonia. J Am Soc Nephrol. 2020;31(6):1157-65.

30. Zhao XY, Xu XX, Yin HS, Hu QM, Xiong T, Tang YY, et al. Clinical characteristics of patients with 2019 coronavirus disease in a non-Wuhan area of Hubei Province, China: a retrospective study. BMC Infect Dis. 2020;20(1):311.

31. Yang F, Shi S, Zhu J, Shi J, Dai K, Chen X. Analysis of 92 deceased patients with COVID-19. J Med Virol. 2020;10.1002/jmv.25891.

32. Yang R, Gui X, Zhang Y, Xiong Y. The role of essential organ-based comorbidities in the prognosis of COVID-19 infection patients. Expert Rev Respir Med. 2020;1-4.

33. Meneses GC, Silva Junior GBD, Tôrres PPBF, Castro VQ, Lopes RL, Martins $A M C$, et al. Novel kidney injury biomarkers in tropical infections: a review of the literature. Rev Inst Med Trop Sao Paulo. 2020;62:e14.

34. Wichmann D, Sperhake JP, Lütgehetmann M, Steurer S, Edler C, Heinemann $A$, et al. Autopsy findings and venous thromboembolism in patients with COVID-19. Ann Intern Med. 2020;M20-2003.

35. Yao XH, Li TY, He ZC, Ping YF, Liu HW, Yu SC, et al. A pathological report of three COVID-19 cases by minimally invasive autopsies. Zhonghua Bing Li Xue Za Zhi. 2020;49(5):411-7. 